\title{
DISTRIBUTION OF DERMATOPHYTES FROM SOILS OF URBAN AND RURAL AREAS OF CITIES OF PARAIBA STATE, BRAZIL
}

Zélia Braz Vieira da Silva PONTES(1), Aurylene Carlos de OLIVEIRA(1), Felipe Queiroga Sarmento GUERRA(1), Luiz Renato de Araújo PONTES(2) \& Jozemar Pereira dos SANTOS(3)

\begin{abstract}
SUMMARY
The dermatophytes, keratinophilic fungi, represent important microorganisms of the soil microbiota, where there are cosmopolitan species and others with restricted geographic distribution. The aim of this study was to broaden the knowledge about the presence of dermatophytes in soils of urban (empty lots, schools, slums, squares, beaches and homes) and rural areas and about the evolution of their prevalence in soils of varying $\mathrm{pH}$ in cities of the four mesoregions of Paraiba State, Brazil. Soil samples were collected from 31 cities of Paraiba State. Of 212 samples, 62\% showed fungal growth, particularly those from the Mata Paraibana mesoregion (43.5\%), which has a tropical climate, hot and humid. Soil pH varied from 4.65 to 9.06 , with $71 \%$ of the growth of dermatophytes occurring at alkaline $\mathrm{pH}(7.02$ - 9.06) $(\rho=0.000)$. Of 131 strains isolated, 57.3\% were geophilic species, particularly Trichophyton terrestre (31.3\%) and Mycrosporum gypseum (21.4\%). M. nanum and T. ajelloi were isolated for the first time in Paraiba State. The zoophilic species identified were T. mentagrophytes var. mentagrophytes $(31.3 \%)$ and T. verrucosum $(7.6 \%)$, and T. tonsurans was isolated as an anthropophilic species. The soils of urban areas including empty lots, schools, slums and squares of cities in the mesoregions of Paraiba State were found to be the most suitable reservoirs for almost all dermatophytes; their growth may have been influenced by environmental factors, soils with residues of human and/or animal keratin and alkaline $\mathrm{pH}$.
\end{abstract}

KEYWORDS: Dermatophytes; Keratinophilic fungi; Soil; pH conditions; Brazil.

\section{INTRODUCTION}

The dermatophytes (Trichophyton, Microsporum and Epidermophyton), keratinophilic fungi, represent important microorganisms of the soil microbiota, where there are cosmopolitan species and others with restricted geographic distribution ${ }^{1,2,6,10,17,21}$. There have been reports of the isolation of T. ajelloi, T. rubrum, T. mentagrophytes, T. verrucosum, T. terrestre, T. tonsurans, $T$. simii, $T$. schoenleinii, M. gypseum, M. canis, M. audouinii, M. nanum, M. cookei and/or E. floccosum, from the soils of various Brazilian states and locals around the world $8,20,24,25,30,32,34$.

The occurrence of fungi in the soil can also be influenced by non-biological factors such as soil temperature, humidity, rainfall, environmental light, climate, chemical composition, quantity of organic matter in the soil and $\mathrm{pH}$. Some have a wide range of tolerance for acidic to alkaline soils $\mathrm{s}^{2,714,16}$. However, studies of soil $\mathrm{pH}$ in relation to occurrence of dermatophytes are uncommon in Brazil.

The study of the diversity of dermatophytes in the soil is important because changes in the distribution of species of dermatophytes due to ecological factors, socio-economic, therapeutic, and migration processes of livestock populations, reflect the epidemiology of dermatophytosis, which are one of the source infections of the soil ${ }^{2,3,16,18,31}$. Thus, the aim of this study was to broaden the study into the presence of dermatophytes from soils of urban and rural areas of cities of four mesoregions of Paraiba State and the influence of $\mathrm{pH}$ on fungi growth.

\section{MATERIALS AND METHODS}

The state of Paraiba is situated in the eastern portion of Northeast Brazil, with coordinates between $6^{\circ}$ and $8^{\circ} \mathrm{S}$ and between $34^{\circ}$ and $38^{\circ} \mathrm{W}$; therefore, it is included in the tropical zone. It comprises an area of 56,372 $\mathrm{km}^{2}$ and is divided into four mesoregions (Mata Paraibana, Borborema, Agreste Paraibano and Sertão Paraibano) and into 23 geographic microregions, including a total of 223 cities. In the Mata Paraibana, the predominant climate is warm, humid tropical (As') with an average annual rainfall of $1,800 \mathrm{~mm}$, temperature of $26^{\circ} \mathrm{C}$ and relative humidity of $80 \%$. The soils are sandy and muddy, which are influenced by sea water and have especially coastal vegetation of mangrove swamp, rainforest and cerrado. In Borborema, the predominant climate is semi-arid (Bsh), warm and dry with average annual rainfall of $500 \mathrm{~mm}$, temperature of $26^{\circ} \mathrm{C}$ and relative humidity of $75 \%$. The soils are shallow stony soil with caatinga 
PONTES, Z.B.V.S.; OLIVEIRA, A.C.; GUERRA, F.Q.S.; PONTES, L.R.A. \& SANTOS, J.P. - Distribution of dermatophytes from soils of urban and rural areas of cities of Paraiba State, Brazil. Rev. Inst. Med. Trop. Sao Paulo, 55(6): 377-83, 2013.

vegetation. The climate Bsh, together with As' are observed in Agreste Paraibano. However, in Sertão Paraibano, the predominant climate is semihumid (Aw') with an average annual rainfall of $800 \mathrm{~mm}$, temperature of $27^{\circ} \mathrm{C}$ and relative humidity of $70 \%$. In the two last mesoregions, a slow development of soils with caatinga vegetation (Fig. 1) ${ }^{28}$.

An ecological study was performed with a total of 212 soil samples. The sampling was non-probabilistic, as it was done by convenience and accessibility to the members of the team, taking into consideration conglomerates of cities in Paraiba mesoregions. Each mesoregion was represented by a city of great geographical and population density: João Pessoa for Mata Paraibana, Monteiro for Borborema, Campina Grande for Agreste Paraibano and Patos for Sertão Paraibano. The other cities were randomly included.
Soil samples were selected from urban (empty lots, schools, slums, squares, homes and beaches) and rural areas of cities. The sampling sites were selected on the basis of the likely presence of soil with keratin residues from humans and animals.

The collection, processing and $\mathrm{pH}$ of soil solutions were according to the techniques described by VANBREUSEGHEM ${ }^{33}$. Approximately $100 \mathrm{~g}$ of soil at a depth of three to five centimeters was collected, placed in polyethylene bags and brought to be processed at the Laboratory of Mycology in the Department of Pharmaceutic Sciences and Laboratory of Ceramic, Department of Mechanical Engineering at the Federal University of Paraiba.

Using a pHmetrer, the $\mathrm{pH}$ of each soil sample (20 g) was measured
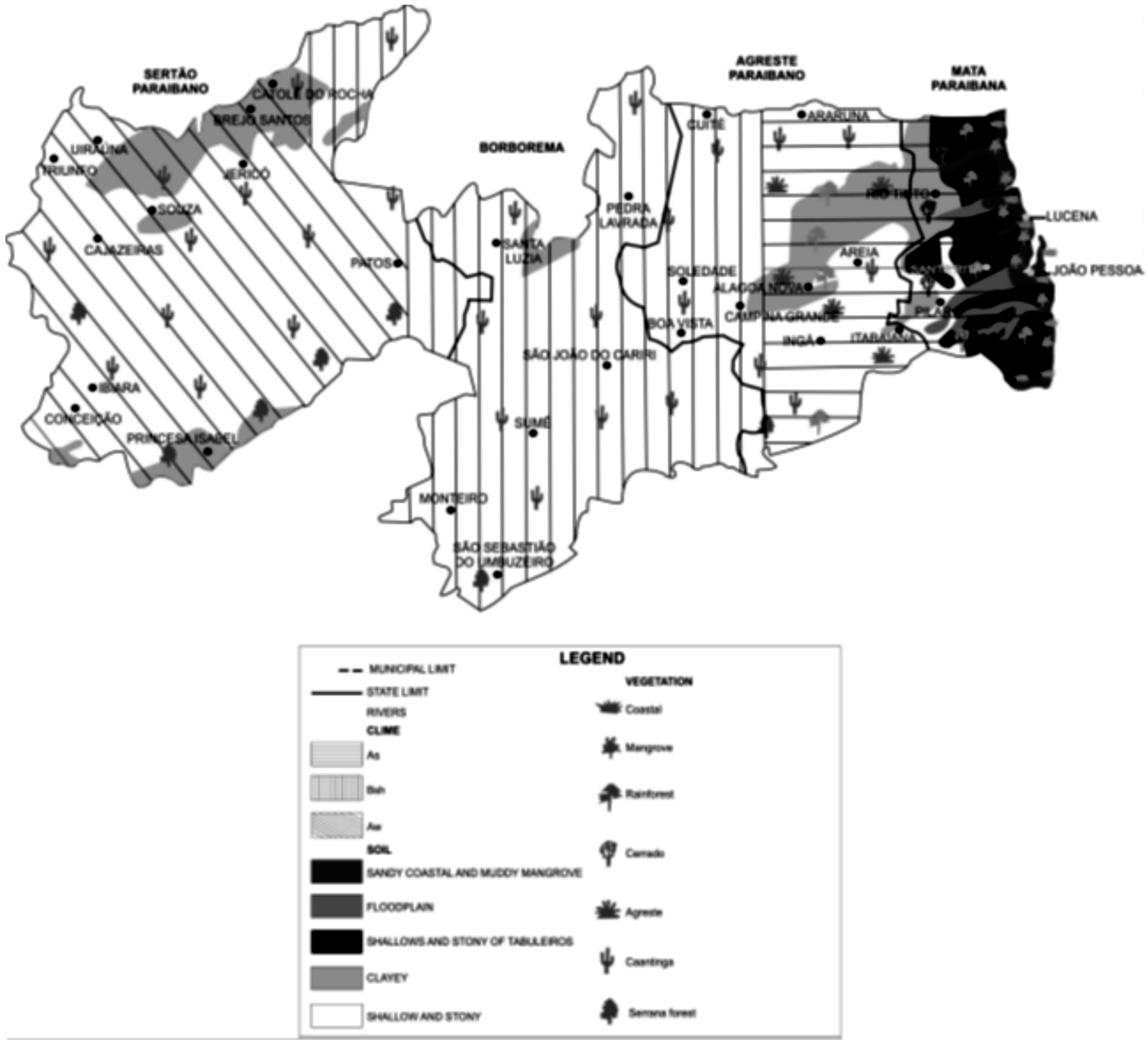

Fig. 1 - Location of 31 cities, according to four mesoregions, soils type, vegetation and climate of the state of Paraíba, Brazil. Adapted from RODRIGUEZ ${ }^{28}$. 


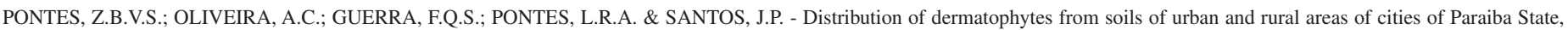
Brazil. Rev. Inst. Med. Trop. Sao Paulo, 55(6): 377-83, 2013.

after dilution in distilled sterile water $(20 \mathrm{~mL})$ with 20 minutes of agitation and decantation. Each sample was distributed in sterile Petri plates, moistened with sterile water $(20 \mathrm{~mL})$ and some sterile human hair strips were placed over each surface. The plates were identified and incubated $\left(27-30^{\circ} \mathrm{C}\right)$ and from the $5^{\text {th }}$ to the $70^{\text {th }}$ day the hair strips were regularly observed with magnifying glasses for signs of fungal growth. Hair strips with a development of prominent fungal growth around them, were placed between slide and cover slid, colored in lactophenol blue cotton and examined in a microscope (10X and 40X). They were cultivated in Sabouraud dextrose agar ${ }^{\circledR}$ medium with chloramphenicol $\left(0.05 \mathrm{mg} \mathrm{mL}^{-1}\right)$ and in Mycobiotic agar ${ }^{\circledR}$ and incubated at room temperature for another minimum period of two weeks.

The identification of the species was based on macromorphology and micromorphology features (slide-culturing) and physiological tests (urea hydrolysis, in vitro hair perforation, vitamin requirement and sensitive media). The classification was based on BARNETT \& HUNTER $^{5}$, REBELL \& TAPLIN ${ }^{27}$ and HOOG et al. ${ }^{12}$.

The data were subjected to statistical analysis, which consisted of the Binomial test. The process was carried out by computing SPSS $13^{22}$, allowing to verify if the dermatophytes growth soil acidic $\mathrm{pH}$ is equal to alkaline $\mathrm{pH}$.

\section{RESULTS}

In 31 cities of four mesoregions of the state of Paraiba (Fig. 1), 62\% of the growth of dermatophytes occurred in soil with different $\mathrm{pH}$. In cities from Mata Paraibana, isolations were observed in $43.5 \%$ of samples, where this rate was $84 \%$ in the capital, João Pessoa. In cities from Sertão Paraibano, the isolation rate was $20.6 \%$, whereas $23.7 \%$ in cities from Agreste Paraibano and $12.2 \%$ in cities from Borborema (Table 1).

A total of 131 strains of dermatophytes were isolated, where $57.3 \%$ of the geophilic species were identified. T. terrestre $(31.3 \%)$ was the most common species, followed by $M$. gypseum $(21.4 \%)$, M. nanum (3\%), T. ajelloi (0.8\%) and Anthroderma gypsea (0.8\%), a teleomorph form of M. gypseum, observed in sample soil. M. nanum and T. ajelloi were isolated for the first time in Paraiba State. The zoophilic species identified included T. mentagrophytes var. mentagrophytes $(31.3 \%)$ and T. verrucosum $(7.6 \%)$. T. tonsurans $(3.8 \%)$ was the only anthropophilic species isolated. The growth of more than one fungal species was observed in 13 samples (Table 1).

The soils that showed the highest rates of dermatophytes were those of urban areas (95\%), especially in soils of empty lots (25.2\% of isolations), around schools (22.9\%), in slums (21.4\%) and squares (19.8\%), compared to around homes $(3.8 \%)$ and on beaches $(2.3 \%)$ (Table 2).

Dermatophytes developed in a wide $\mathrm{pH}$ range: acid to alkaline (4.65 - 9.06), with $71 \%$ in alkaline $\mathrm{pH}(7.02$ - 9.06). T. terrestre develops within the $\mathrm{pH}$ range of $5.76-8.90$. T. mentagrophytes var. mentagrophytes and $M$. gypseum develop within the $\mathrm{pH}$ range 4.65 9.06 and $5.77-8.31$, respectively and $T$. verrucosum was reported from urban areas at $\mathrm{pH} 6.65-8.05$. In acid pH soil, an inhibition of growth M. nanum, A. gypsea and T. ajelloi was observed. The dermatophytes growth in soil of alkaline $\mathrm{pH}$ was significantly different from the acidic $\mathrm{pH}(\rho=0.000)$ (Table 3$)$.

\section{DISCUSSION}

Studies worldwide have examined various variables, such as soil type, $\mathrm{pH}$, climate, temperature, moisture and organic matter content, and have revealed the presence of dermatophytes and other keratinophilic fungi in soil ${ }^{1,3,6,9,14,21,31}$. In Brazil, there are few reports on the isolation of dermatophytes in soil, specifically in the Northeast region ${ }^{16,26,32}$. In the mesoregion of Mata Paraibana, with an As' climate and sandy and muddy soils ${ }^{28}$, dermatophytes were isolated in $43.5 \%$ of samples. A previous study reported that $55.7 \%$ of 68 soil samples from the city of João Pessoa-Paraiba State (PB), showed the growth of dermatophytes ${ }^{26}$. In Borborema, the isolation rate was $12.2 \%$. This area has a Bsh climate and shallow rocky soil. In other mesoregions, the lack of water for prolonged periods accounts for the slow development of soil. The distribution of climates is related to the geographic localization, that is, the closer to the coast the more humid and the farther from the coast the drier. The four mesoregions of Paraiba have predominantly caatinga vegetation, except Mata Paraibana ${ }^{28}$. Although the roles of fungi in ecosystems have been well documented, knowledge about their population dynamics and community structure and of the diversity of soil fungi is still poor. Further studies of Paraiba soils are necessary to analyze the changes and influence of variables such as types of climate, soil and vegetation on the development of dermatophytes.

The $\mathrm{pH}$ range of $7.2-8.0$ is favorable for the production of proteolytic enzymes (keratinases) by keratinophilic fungi, which are necessary for their growth, along with other soil conditions ${ }^{15}$. However, the results of this study indicate the growth of dermatophytes in acid and alkaline $\mathrm{pH}$, where $71 \%$ of isolations were observed in the alkaline $\mathrm{pH}$ range between 7.02 and 9.06 ( $\rho=0.000)$. These results, obtained with different soil samples, confirm the importance of $\mathrm{pH}$ in the habitat to the occurrence and distribution of dermatophytes. In acidic soils, there is growth inhibition of dermatophytes and other keratinophilic fungi, but soils that are weakly acidic to neutral or alkaline are optimal for their growth ${ }^{14,16,21,23}$. In this investigation, in acid $\mathrm{pH}$ soils, the growth of A. gypseum, M. nanum and T. ajelloi was inhibited. Some authors ${ }^{6}$ observed that the frequency of T. ajelloi $(33 \%)$ increased with a decrease in $\mathrm{pH}$, reaching a maximum in strongly acidic soil.

Eight species of dermatophytes were identified in the soils of cities in Paraiba. Of the geophilic species (57.3\%), T. terrestre $(31.3 \%)$ was especially found in soils from squares, empty lots, schools, slums and beaches. This variable distribution rate can be related to the sampling sites, where the presence of people and animals are frequent, providing residues of organic matter, which are essential for the growth of these fungi. The results obtained are close to those for other cities in Brazil such as: Belo Horizonte and São Paulo ${ }^{29}$ and in soils of countries such as Germany and Argentina ${ }^{7,21}$. However, the frequency of this species was low in Italy ${ }^{25}$ and India ${ }^{31}$. T. terrestre has been found to be a pathogen particularly in pets and humans including the elderly who exhibit complications related to immunological factors ${ }^{25}$.

Other geophilic species that were isolated included M. gypseum (21.4\%), M. nanum (3\%), T. ajelloi $(0.8 \%)$ and A. gypsea $(0.8 \%)$ at alkaline $\mathrm{pH}$, except $M$. gypseum, which also showed growth at acid $\mathrm{pH}$. Similar results were obtained in soils from the Brazilian states of Rio de Janeiro $(31 \%)^{10}$, São Paulo $(30 \%)^{29}$ and Bahia $(28.8 \%)^{32}$. However, in Recife, Pernambuco State, $5.6 \%$ isolation was observed for this species 
PONTES, Z.B.V.S.; OLIVEIRA, A.C.; GUERRA, F.Q.S.; PONTES, L.R.A. \& SANTOS, J.P. - Distribution of dermatophytes from soils of urban and rural areas of cities of Paraiba State, Brazil. Rev. Inst. Med. Trop. Sao Paulo, 55(6): 377-83, 2013.

Table 1

Dermatophytes isolated from urban and rural soil samples from 31 cities in four mesoregions of Paraiba State

\begin{tabular}{|c|c|c|c|c|c|c|c|c|c|c|c|}
\hline \multirow{2}{*}{ Mesoregions } & \multirow[b]{2}{*}{ Cities } & \multirow[b]{2}{*}{$\begin{array}{c}\text { Soil* } \\
\mathrm{n}\end{array}$} & \multicolumn{9}{|c|}{ Dermatophytes** } \\
\hline & & & $\begin{array}{c}A . g \\
\mathrm{n}\end{array}$ & $\begin{array}{c}M . g \\
\mathrm{n}\end{array}$ & $\begin{array}{c}M . n \\
\mathrm{n}\end{array}$ & $\begin{array}{c}\text { T. } a \\
\mathrm{n}\end{array}$ & $\begin{array}{c}\text { T.m } \\
\mathrm{n}\end{array}$ & $\begin{array}{c}\text { T.te } \\
\mathrm{n}\end{array}$ & $\begin{array}{c}\text { T.t } \\
\mathrm{n}\end{array}$ & $\begin{array}{c}\text { T.v } \\
\mathrm{n}\end{array}$ & $\begin{array}{c}\text { Total } \\
n\end{array}$ \\
\hline \multirow{5}{*}{ Mata Paraibana } & João Pessoa & 68 & 1 & 10 & - & - & 18 & 12 & 2 & 5 & 48 \\
\hline & Lucena & 4 & - & - & - & - & - & 1 & 1 & - & 2 \\
\hline & Pilar & 5 & - & 1 & - & - & 1 & 1 & - & - & 3 \\
\hline & Rio Tinto & 5 & - & - & - & - & 1 & - & - & - & 1 \\
\hline & Santa Rita & 3 & - & 1 & - & - & - & 1 & - & 1 & 3 \\
\hline \multicolumn{2}{|c|}{ Subtotal } & 85 & 1 & 12 & - & - & 20 & 15 & 3 & 6 & 57 \\
\hline \multirow{9}{*}{ Agreste Paraibano } & Alagoa Nova & 7 & - & 1 & - & - & - & - & - & 1 & 2 \\
\hline & Araruna & 4 & - & 1 & 1 & - & - & 3 & - & - & 5 \\
\hline & Areia & 3 & - & - & - & - & - & 1 & - & - & 1 \\
\hline & Boa vista & 4 & - & 1 & - & - & 3 & - & - & - & 4 \\
\hline & C. Grande & 6 & - & 1 & - & - & - & - & - & - & 1 \\
\hline & Cuité & 4 & - & 2 & - & - & 2 & - & - & 1 & 5 \\
\hline & Ingá & 4 & - & - & - & - & - & 2 & - & - & 2 \\
\hline & Itabaiana & 8 & - & - & 1 & - & - & 2 & - & 1 & 4 \\
\hline & Soledade & 3 & - & 1 & - & - & - & 2 & - & - & 3 \\
\hline \multicolumn{2}{|c|}{ Subtotal } & 43 & - & 7 & 2 & - & 5 & 10 & - & 3 & 27 \\
\hline \multirow{6}{*}{ Borborema } & Monteiro & 4 & - & - & - & - & 1 & - & - & - & 1 \\
\hline & Pedra Lavrada & 2 & - & - & - & - & - & 2 & - & - & 2 \\
\hline & São João Cariri & 6 & - & - & - & - & 3 & - & - & 1 & 4 \\
\hline & S. S.Umbuzeiro & 3 & - & - & - & - & - & 2 & - & - & 2 \\
\hline & Santa Luzia & 4 & - & - & 1 & - & 1 & 1 & - & - & 3 \\
\hline & Sumé & 12 & - & - & - & 1 & 2 & 1 & - & - & 4 \\
\hline \multicolumn{2}{|c|}{ Subtotal } & 31 & - & - & 1 & 1 & 7 & 6 & - & 1 & 16 \\
\hline \multirow{11}{*}{ Sertão Paraibano } & Brejo Santos & 7 & - & 1 & - & - & - & 1 & 1 & - & 3 \\
\hline & Cajazeiras & 4 & - & 1 & - & - & 4 & - & - & - & 5 \\
\hline & Catolé Rocha & 5 & - & 3 & - & - & - & 1 & - & - & 4 \\
\hline & Conceição & 6 & - & - & - & - & - & 2 & - & - & 2 \\
\hline & Ibiara & 4 & - & - & 1 & - & - & - & - & - & 1 \\
\hline & Jericó & 3 & - & 1 & - & - & 3 & - & - & - & 4 \\
\hline & Patos & 4 & - & - & - & - & - & 1 & - & - & 1 \\
\hline & Princesa Isabel & 6 & - & 1 & - & - & 1 & 3 & - & - & 5 \\
\hline & Souza & 3 & - & 2 & - & - & - & - & - & - & 2 \\
\hline & Triunfo & 6 & - & - & - & - & 1 & 2 & - & - & 3 \\
\hline & Uiraúna & 5 & - & - & - & - & - & - & 1 & - & 1 \\
\hline \multicolumn{2}{|c|}{ Subtotal } & 53 & - & 9 & - & - & 9 & 10 & 2 & - & 31 \\
\hline \multicolumn{2}{|l|}{ Total } & 212 & 1 & 28 & 4 & 1 & 41 & 41 & 5 & 10 & 131 \\
\hline
\end{tabular}

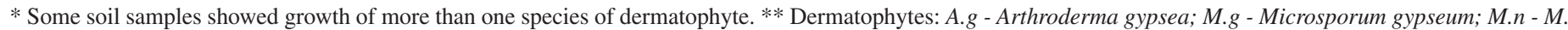
nanum; T.a - Trichophyton ajelloi; T.m - T. mentagrophytes var. mentagrophytes; T.te - T. terrestre; T.to - T. tonsurans; T.v - T. verrucosum.

at alkaline $\mathrm{pH}^{16}$. High rates of $M$. gypseum were observed in soils from Rio Grande do Sul, Brazil $(79 \%)^{8}$, Argentina $(89 \%)^{13}$, India $(64 \%)^{4}$, Kuwait $(50 \%)$ in parks and gardens ${ }^{1}$, and Italy $(39 \%)^{25}$.

M. gypseum has a universal distribution, and it is the etiological agent of tinea capitis and tinea corporis in humans and animals, where dogs, horses and rodents are common reservoirs of keratin ${ }^{1}$. In this investigation, it was found in soils of empty lots, slums, schools, squares, homes and rural areas. HAYASHI \& TOSHITANI ${ }^{11}$ reported, in Japan, 271 cases of human infection by this fungal species. A case of tinea capitis due to infection by this species, has been diagnosed in João Pessoa-PB ${ }^{18}$. 


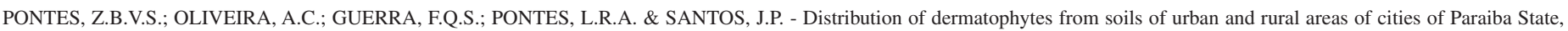
Brazil. Rev. Inst. Med. Trop. Sao Paulo, 55(6): 377-83, 2013.

Table 2

Distribution of dermatophytes from soil samples of urban and rural areas of cities of Paraiba State

\begin{tabular}{|c|c|c|c|c|c|c|c|c|}
\hline & \multicolumn{6}{|c|}{ Urban Area } & \multirow{2}{*}{$\begin{array}{c}\text { Rural Area } \\
n\end{array}$} & \multirow{2}{*}{$\begin{array}{l}\text { Total } \\
\mathrm{n}(\%)\end{array}$} \\
\hline & $\begin{array}{c}\text { School* } \\
\mathrm{n}\end{array}$ & $\underset{\mathrm{n}}{\text { Square* }}$ & $\underset{\mathrm{n}}{\text { Empty lot* }}$ & $\underset{\mathrm{n}}{\text { Slum* }}$ & $\underset{\mathrm{n}}{\text { Residence }}$ & $\begin{array}{c}\text { Beach } \\
n\end{array}$ & & \\
\hline \multicolumn{9}{|l|}{ Soils Samples } \\
\hline Negative & 21 & 23 & 15 & 12 & 07 & 06 & 14 & $94(44.3)$ \\
\hline Positive & 28 & 24 & 29 & 23 & 05 & 03 & 06 & $118(55.7)$ \\
\hline \multicolumn{9}{|l|}{ Dermatophytes } \\
\hline Trichophyton terrestre & 10 & 12 & 11 & 07 & - & 01 & - & $41(31.3)$ \\
\hline T. mentagrophytes var. mentagrophytes & 11 & 08 & 08 & 07 & 02 & 01 & 04 & $41(31.3)$ \\
\hline T. verrucosum & 01 & 02 & 03 & 04 & - & - & - & $10(7.6)$ \\
\hline T. tonsurans & 02 & - & 01 & 01 & - & 01 & - & $05(3.8)$ \\
\hline T. ajelloi & 01 & - & - & - & - & - & - & $01(0.8)$ \\
\hline Microsporum gypseum & 03 & 03 & 09 & 08 & 03 & - & 02 & $28(21.4)$ \\
\hline M. nanum & 02 & 01 & 01 & - & - & - & - & $04(3.0)$ \\
\hline Anthroderma gypsea & - & - & - & 01 & - & - & & $01(0.8)$ \\
\hline Total & 30 & 26 & 33 & 28 & 05 & 03 & 06 & 13 \\
\hline$(\%)$ & (22.9) & (19.8) & $(25.2)$ & $(21.4)$ & $(3.8)$ & $(2.3)$ & $(4.6)$ & $(100.0)$ \\
\hline
\end{tabular}

* Some soil samples showed growth of more than one species of dermatophytes.

Table 3

Distribution of dermatophytes, with reference to soil $\mathrm{pH}$

\begin{tabular}{lccc}
\hline & \multicolumn{3}{c}{ Soil $\mathrm{pH}$} \\
\cline { 2 - 4 } Dermatophytes & $\begin{array}{c}\text { Acid } \\
4.65-6.65\end{array}$ & $\begin{array}{c}\text { Alkaline } \\
7.02-9.06\end{array}$ & $\begin{array}{c}\text { Total } \\
\mathrm{n}(\%)\end{array}$ \\
\hline $\begin{array}{l}\text { Trichophyton terrestre } \\
\text { T. mentagrophytes var. }\end{array}$ & 09 & 32 & $41(31.3)$ \\
mentagrophytes & 16 & 25 & $41(31.3)$ \\
T. verrucosum & 02 & 08 & $10(7.6)$ \\
T. tonsurans & 01 & 04 & $05(3.8)$ \\
T. ajelloi & - & 01 & $01(0.8)$ \\
Microsporum gypseum & 10 & 18 & $28(21.3)$ \\
M. nanum & - & 04 & $04(3.1)$ \\
Anthroderma gypsea & - & 01 & $01(0.8)$ \\
\hline Total n (\%) & $38(29 \%)$ & $93(71 \%)$ & $131(100.0)$ \\
\hline Bing & & &
\end{tabular}

Binomial test. $\mathrm{H}_{0}$ : acid $\mathrm{pH}=$ alkaline $\mathrm{pH}$ and $\mathrm{H}_{1}$ : acid $\mathrm{pH} \neq$ alkaline $\mathrm{pH}$; $\rho=0.000 \leq 0.05$, reject $\mathrm{H}_{0}$.

M. nanum (3\%) was isolated for the first time from soil of schools, beaches and empty lots in Paraiba State. In a study carried out on soil of a swimming resort, in Mexico, its isolation rate was $5 \%{ }^{19}$.

T. ajelloi was isolated from soils of the South and Southeast regions of Brazil ${ }^{8,10,29}$. ALVAREZ et al. ${ }^{2}$ reported an isolation rate of $66 \%$ for this fungus in soil of Argentina. In this study, the first and only isolation of this species $(0.8 \%)$ was observed in soil around a school.

Among the zoophilic species, T. mentagrophytes var. mentagrophytes was the species of highest incidence in soils of various places (schools, gardens, parks, beaches, caverns, chicken coops, pens and homes) in some Brazilian states such as Amazonas, São Paulo and Goias ${ }^{29,34,35}$, as well as soils of Mexico, Iran, Nigeria and India ${ }^{4,19,24,30,31}$. In this study, this species $(31.3 \%)$ was isolated from all soils of urban and rural areas, and one strain of this species was reported in highly acidic soil at $\mathrm{pH}$ 4.65. In Berlin, the average $\mathrm{pH}$ of positive keratinophilic fungal samples was $5.8^{7}$, and in India, it was the most common isolated species from pH 6.5 to 9.5 soils $^{14}$.

T. verrucosum is a zoophilic species cited as the agent encountered in the case of cattle, which can be transmitted to humans. It is usually highly inflammatory involving the scalp, beard or exposed area of body $^{3,18}$. In this investigation, T. verrucosum was reported from urban areas at $\mathrm{pH} 6.65-8.05$.

The isolation rate of $T$. tonsurans as an anthropophilic species was $3.8 \%$ in soils of schools, slums, beaches and empty lots and $80 \%$ at alkaline $\mathrm{pH}$. GOULART et al. ${ }^{10}$ also reported the isolation of this species in the soil of Rio of Janeiro. In Recife, an epidemiological correlation has been observed between $T$. tonsurans isolated from soils of parks I $(28 \%)$ and II (20\%) and dermatophytosis agents ${ }^{16,18}$.

\section{CONCLUSION}

The soils of urban areas within empty lots, schools, slums and 
PONTES, Z.B.V.S.; OLIVEIRA, A.C.; GUERRA, F.Q.S.; PONTES, L.R.A. \& SANTOS, J.P. - Distribution of dermatophytes from soils of urban and rural areas of cities of Paraiba State, Brazil. Rev. Inst. Med. Trop. Sao Paulo, 55(6): 377-83, 2013.

squares of cities of mesoregions of Paraiba State were found to be the most suitable reservoirs for almost all dermatophytes. Its growth may have been influenced by environmental factors such as residues of human and/or animal keratin and alkaline $\mathrm{pH}$.

\section{RESUMO}

\section{Distribuição de dermatófitos isolados de solos de cidades do Estado da Paraíba, Brasil}

Os dermatófitos, fungos queratinofílicos, representam importantes microrganismos da microbiota do solo, onde existem espécies cosmopolitas e outras de distribuição geográfica restrita. Este estudo teve como objetivo ampliar o conhecimento da distribuição de dermatófitos do solo proveniente de áreas urbanas (terrenos baldios, escolas, favelas, praças, praias e residências) e rurais de quatro mesorregiões paraibanas e da influência do pH na adaptação desse grupo de fungos. Amostras de solos urbanos e rurais foram coletadas de 31 cidades do estado da Paraíba, Brasil. De 212 amostras $62 \%$ apresentaram crescimento fúngico, destacando-se a Mesorregião da Mata Paraibana (43.5\%), a qual apresenta clima tropical, quente e úmido. $\mathrm{O}$ pH das amostras de solo variou de 4.65 a 9.06, com crescimento de $71 \%$ dos dermatófitos em $\mathrm{pH}$ alcalino (7.02 - 9.06) $(\rho=0.000)$. Das 131 cepas isoladas $57.3 \%$ eram espécies geofílicas, destacando-se Trichophyton terrestre (31.3\%) e Microsporum gypseum (21.4\%). M. nanum e T. ajelloi foram isolados pela primeira vez no estado da Paraíba. Entre as espécies zoofílicas foram identificadas T. mentagrophytes var. mentagrophytes $(31.3 \%)$ e T. verrucosum $(7.6 \%)$ e como espécie antropofílica foi isolada T. tonsurans. Os solos de terrenos baldios, escolas, favelas e praças de cidades paraibanas são os reservatórios mais adequados dos dermatófitos, cujo crescimento pode ter sido influenciado por fatores ambientais, solos com resíduos de queratina humana e ou animal e $\mathrm{pH}$ alcalino.

\section{ACKNOWLEDGEMENTS}

The authors would like to thank to the Laboratory of Ceramics for collecting and measuring the $\mathrm{pH}$ of soils samples.

\section{REFERENCES}

1. Al-Musallam AA, Al-Zarban SS, Al-Sanè NA, Ahmed TM. A report on the predominant occurrence of a dermatophytes species in cultivated soil from Kuwait. Mycopathologia. 1995;130:159-61.

2. Alvarez DP, Luque AG, Marini P. Influencia del sustrato queratinoso de suelos de Pradera sobre la colonización por dermatofitos geofílicos. Bol Micol. 1986;3:25-9.

3. Amaral CDP, Pereira DIB, Meireles MCA. Caracterização da microbiota por fungos filamentosos no tratamento hípico de bovinos de corte. Ci Rural. 2011;41:2137-42.

4. Anbu P, Hilda A, Gopinath SC. Keratinophilic fungi of poultry farm and feather dumping soil in Tamil Nadu, India. Mycopathologia. 2004;158:303-9.

5. Barnett HL, Hunter BB. Illustrated genera of imperfect fungi. $4^{\text {th }}$ ed. New York: Burgess; 1986.

6. Bohacz J, Kowalska TK. Species diversity of keratinophilic fungi in various soil types. Cent Eur J Biol. 2012;7:259-66.

7. Böhme H, Ziegler W. The distribution of geophilic dermatophytes and other keratinophilic fungi in relation to the $\mathrm{pH}$ of the soil. Mycopathol Mycol Appl. 1969;38:247-55.
8. Fischman O, Ramos CD. Geophilic dermatophytes recovered from Rio Grande do Sul soil. Mycopathol Mycol Appl. 1967;33:157-60.

9. Ganaie MA, Sood S, Rizvi G, Khan TA. Isolation and identification of keratinophilic fungi from different soil samples in Jhansi city (India). Plant Pathol J. 2010;9:194-7.

10. Goulart EG, Lima SMF, Carvalho MA, Oliveira JA, Jesus MM, Campos RE, et al. Isolamento de fungos patogênicos do solo no município do Rio de Janeiro, RJ, Brasil. Folha Méd. 1986;93:15-20.

11. Hayashi N, Toshitani S. Human infections with Microsporum gypseum in Japan. Mykosen. 1983;26:337-45.

12. Hoog GS, Guarro J, Figueras MJ. Atlas of clinical fungi. $2^{\text {nd }}$ ed. Utrecht: Centraalbureau voor Schimmelcultures; 2000. 1126p.

13. Iovannitti CA, Malliarchuk O, Casanova A, Dawson M. Estudio micológico en muestras de tierra de la ciudad de la Plata. Rev Argent Micol. 1985;8:9-11.

14. Jain N, Sharma M. Distribution of dermatophytes and other related fungi in Jaipur city, with particular reference to soil pH. Mycoses. 2011;54:52-8.

15. Kaul S, Sumbali G. Impact of some ecological factors on the occurrence of poultry soil-inhabiting keratinophiles. Mycopathologia. 1998;143:155-9.

16. Leal AFG, Macêdo DPC, Laranjeira D, Souza-Motta CM, Fernandes MJS, Magalhães OMC, et al. Correlação epidemiológica entre fungos queratinofílicos isolados do solo e agentes de dermatomicoses. Rev Soc Bras Med Trop. 2009;42:471-3.

17. Lee MJ, Park JS, Chung H, Jun JB, Bang YJ. Distribuition of soil keratinophilic fungi isolated in summer beaches of the east sea in Korea. Korea J Med Mycol. 2011;16:44-50.

18. Lima OE, Pontes ZBVS, Oliveira NMC, Carvalho MFFP, Guerra MFL, Santos JP. Freqüência de dermatofitoses em João Pessoa, Paraíba, Brasil. An Bras Dermat. 1999;74:127-32.

19. López Martínez R. Investigación de algunas fuentes de infección en las dermatofitoses: estudio de suelos, animales y hombre. Gac Méd Méx. 1986;122:167-72.

20. Mahmoudabadi AZ, Zarrin M. Isolation of dermatophytes and related keratinophilic fungi from the two public parks in Ahvaz. Jundishapur J Microbiol. 2008;1:20-3.

21. Mangiaterra ML, Alonso JM. Keratinophilic fungi in soils of Corrientes city (Argentina). Bol Micol. 1989;4:129-33.

22. Norusis MJ. SPSS for Windows-Base System User's Guide, Release 13.0. Chicago: SPSS.

23. Ogbonna CI, Pugh GJ. Keratinophilic fungi from Nigerian soil. Mycopathologia. 1987;99:115-8.

24. Oyeka CA, Okoli I. Isolation of dermatophytes and non-dermatophytic fungi from soil in Nigeria. Mycoses. 2003;46:336-8.

25. Papini R, Mancianti F, Grassotti G, Cardini G. Survey of keratinophilic fungi isolated from city park soils of Pisa, Italy. Mycopathologia. 1998;143:17-23.

26. Pontes ZBVS, Oliveira AC. Dermatophytes from urbain soils in João Pessoa, Paraíba, Brazil. Rev Arg Microbiol. 2008;40:161-3.

27. Rebell G, Taplin D. Dermatophytes: their recognition and identification. Coral Gables University of Miami; 1974.

28. Rodriguez JL. Atlas escolar da Paraíba. 3. ed. João Pessoa: Grafiset; 2002.

29. Rogers AL, Beneke EJ. Human pathogenic fungi recovered from Brazilian soil Mycopathol Mycol Appl. 1964;22:15-20. 


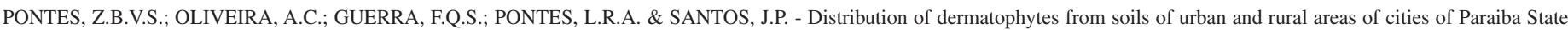
Brazil. Rev. Inst. Med. Trop. Sao Paulo, 55(6): 377-83, 2013.

30. Shadzi S, Chadeganipour M, Alimoradi M. Isolation of keratinophilic fungi from elementary schools and public parks in Isfahan, Iran. Mycoses. 2002;45:496-9.

31. Sharma M. Incidence of dermatophytes and other keratinophilic fungi in the schools and college playground soils of Jaipur, India. Afr J Microbiol Res. 2010;4:2647-54

32. Silva ME. Ocorrência de Cryptococcus neoformans e Microsporum gypseum em solos da Bahia, Brasil. Bol Fund Gonçalo Moniz. 1960;17:1-14.

33. Vanbreuseghem R. Technique biologique pour l'isolement des dermatophytes de sol. Ann Soc Belge Méd Trop. 1952;32:173-8.
34. Vilela EM, Moraes MAP. Isolamento de Microsporum gypseum e Trichophyton mentagrophytes no solo da cidade de Manaus, Amazonas (Brasil). Rev Inst Med Trop Sao Paulo. 1962;4:299-301.

35. Zampronha VCC, Oliveira IP, Monteiro MSR, Souza H, Santos KJG, Araújo AA Isolamento e identificação de dermatófitos presentes no contínuo do solo de cerrado do campus II da Universidade Católica de Goiás. Rev Eletrôn Fac Montes Belos 2005; $1: 37-46$

Received: 16 January 2012

Accepted: 28 March 2013 